\title{
The relationship of trauma severity and mortality with cardiac enzymes and cytokines at multiple trauma patients
}

\author{
Çoklu travmalı olgularda kalp enzimleri ve sitokinler ile \\ travma şiddeti ve mortalitenin ilişkisi
}

\author{
Ali KARAKUŞ, ${ }^{1}$ Zeynep KEKEÇ, ${ }^{2}$ Ramazan AKÇAN, ${ }^{3}$ Gülşah SEYDAOĞLU ${ }^{4}$
}

\section{BACKGROUND}

In this study, we aimed to determine the effects of trauma severity on cardiac involvement through evaluating the trauma severity score together with diagnostic tests in multiple trauma patients. A trauma score was determined using various trauma severity scales.

\section{METHODS}

After obtaining the approval of the ethics committee of the faculty, this prospective study was performed through evaluating 100 multiple trauma patients, aged over 15 years, who applied to our Emergency Department (ED). After determining the trauma severity score using instruments such as the Injury Severity Score (ISS), Glasgow Coma Scale (GCS), and Revised Trauma Score (RTS), the cardiac condition was evaluated using biochemical and radiological diagnostic tests.

\section{RESULTS}

During the study period, 100 patients were evaluated (78 male, 22 female; mean age: $33.2 \pm 15.4$; range 15 to 70 years). It was determined that $92(92 \%)$ were blunt trauma cases, and $77(77 \%)$ of them were due to traffic accidents. The majority of cases showed electrocardiogram (ECG) abnormalities $(63 \%)$ and sinus tachycardia (36\%). Abnormal echocardiogram (ECHO) findings, mostly accompanied by ventricular defects $(n=24)$, were determined in 31 of the cases. Nineteen cases with high trauma severity score resulted in death, and 14 of all deaths were secondary to traffic accidents. Trauma scores were found to show a significant difference between the two groups.

\section{CONCLUSION}

The ISS trauma scale was determined to be the most effective in terms of indicating heart involvement in patients with multiple traumas. Close follow-up and cardiac monitoring should be applied to patients with high trauma severity scores considering possible cardiac rhythm changes and hemodynamic disturbances due to cardiac involvement.

Key Words: Cardiac involvement; cardiac markers; multiple trauma; trauma severity scales.

${ }^{1}$ Department of Emergency Medicine, Mustafa Kemal University Faculty of Medicine, Hatay; Departments of ${ }^{2}$ Emergency Medicine, ${ }^{4}$ Biostatistics,

Cukurova University Faculty of Medicine, Adana; ${ }^{3}$ Department of Forensic Medicine, Hacettepe University Faculty of Medicine, Ankara, Turkey.
AMAÇ

Çalışmamızda çeşitli travma şiddet ölçekleriyle zedelenme oranlarını belirlediğimiz çoklu travma hastalarında; bu şiddet oranlarının kalp etkilenimi üzerine etkilerini yardımcı tanı araçları ile birlikte değerlendirerek kıyaslamayı hedefledik.

\section{GEREÇ VE YÖNTEM}

İleriye dönük olarak planlanan bu çalışma, fakülte etik kurul onayı alındıktan sonra acil servise başvuran 15 yaşın üzerinde çoklu travmalı 100 hasta değerlendirilerek yapıldı. Hastalarda yaralanma şiddeti ölçeği (ISS), Glaskow koma skalası (GCK), revize edilmiş travma skoru (RTS) gibi travma şiddet ölçekleri kullanılarak travmanın şiddeti belirlendikten sonra, biyokimya ve radyolojik tanı araçlarından faydalanılarak kalp etkilenimi değerlendirildi.

\section{BULGULAR}

Çalışma süresince 100 hasta (78 erkek, 22 kadın; ortalama yaş 33; dağılım 15-70 yaş) değerlendirildi. Çoklu travma hastalarının 92'sinin (\%92) künt travma, bunlardan da 77 'sinin (\%77) trafik kazası sonucu olduğu belirlendi. Hastaların \%63'ünde çoğunluğu sinüs taşikardisi (\%36) olan elektrokardiyogramda (EKG) bozukluğu bulgusu görüldü. Olguların 31 'inde çoğunluğunu ventrikül işlev bozukluğunun $(\mathrm{n}=24)$ oluşturduğu anormal ekokardiyogram (EKO) bulguları saptandı. Travma şiddeti yüksek olan 19 olgunun 14'ü trafik kazası nedeniyle hayatını kaybetti. İki grup arasında travma skorları istatistiksel olarak anlamliydi.

\section{SONUÇ}

Çoklu travma hastalarında kalp etkilenimini en iyi gösteren travma ölçeğinin ISS olduğu belirlendi. Yüksek travma şiddetine sahip çoklu travmalı hastalara, kalp etkilenimi olabileceği düşünülerek, kalp ritm bozukluğu ve hemodinamik bozukluk açısından kalp monitörizasyonu ve yakın takip yapılmalıdır.

Anahtar Sözcükler: Kalp etkilenimi; kalp belirteçleri; çoklu travma; travma şiddet ölçekleri.

${ }^{1}$ Mustafa Kemal Üniversitesi Tıp Fakültesi, Acil Tıp Anabilim Dalı, Hatay Çukurova Üniversitesi Tıp Fakültesi, ${ }^{2}$ Acil Tıp Anabilim Dall, ${ }^{4}$ Biyoistatistik Anabilim Dalı, Adana; ${ }^{3}$ Hacettepe Üniversitesi Tip Fakültesi Adli Tıp Anabilim Dalı, Ankara. 
The term multiple trauma describes trauma-related damage involving multiple body cavities or body parts. Being among the leading causes of death and responsible for high morbidity and mortality rates, multiple traumas constitute an important public health problem. ${ }^{[1]}$ In our country, 111,565 beating cases and 929,304 traffic collisions resulting in death (4228 cases) and injury (183,841 cases) were recorded in 2008.

It is known that one-third of hospitalized cases are due to chest trauma, which is responsible for $20-25 \%$ of multiple trauma-related deaths. ${ }^{[1,2]}$ In order to determine and treat cardiac rhythm changes in multiple trauma patients in the early period, frequent examination and close follow-up with cardiac monitoring are of high importance. Troponin T (TnT) and troponin I (TnI) are regarded as the featured indicators in slight cardiac injuries. ${ }^{[3,4]}$ Changes in levels of tumor necrosis factor (TNF)-alpha might be determined due to myocyte damage secondary to cardiac spasm-traumatic cardiac injuries. ${ }^{[5]}$

Ideal trauma grading systems should target the correct definition of all damage and the severity of each type of damage. Additionally, it should be applicable with acceptable features in trauma centers.

\section{MATERIALS AND METHODS}

Multiple trauma patients ( $\mathrm{n}=100)$ admitted to $\mathrm{Cu}$ kurova University, Faculty of Medicine, Emergency Department (ED) were included in the scope of this prospective clinical study. Approval of the ethical committee and informed consent of each case were obtained.

During the study period, the total number of patients admitted to Cukurova University ED was 28,033 , while the number of all patients with trauma was $1,108(3.95 \%)$. Of these, 100 patients with multiple trauma with involvement of at least two body parts were included in the scope of the study.

In the present study, Injury Severity Score (ISS) and Revised Trauma Score (RTS) were used to determine trauma severity; Glasgow Coma Scale (GCS) was used to determine consciousness. The patients were divided into two groups using critical values of each scale as severe or slight traumatic injury. The critical value for ISS was accepted as 15, for RTS 11, and for GCS 8.

\section{Cardiologic Evaluation}

Creatine kinase-MB fraction (CK-MB): Electrochemiluminescence immunoassay (ECLIA) analyzers, Modular Analytics E170 (Elecsys module) and Roche Elecsys 1010/2010 method were used. Normal range was regarded as $0.97-4.94 \mathrm{ng} / \mathrm{ml}$.

CK: Roche/Hitachi: ACN 057 method was used.
Normal values were regarded as $<170 \mathrm{U} / \mathrm{L}$.

TnT: Electrochemiluminescence immunoassay (ECLIA) analyzers, Modular Analytics E170 (Elecsys module) and Roche Elecsys 2010 method were used. Normal values were regarded as $<0.1 \mathrm{ng} / \mathrm{ml}$.

TNF-alpha: TNF-alpha was studied with Micro Elisa method and Biosorc (Belgium) mark kits. Normal values were regarded as $0.4-3.6 \mathrm{pg} / \mathrm{ml}$.

Echocardiogram (ECHO): The patients were evaluated using ECHO and mobile ECHO Device 3.5 megahertz probe in the Cardiology Laboratory.

\section{Statistical Analysis}

In order to analyze the permanent factors, Spearman correlation test and Mann-Whitney $U$ tests were used. While analyzing the categorical factors, chisquare test was used. A $p$ value of $<0.05$ was accepted as statistically significant. The data was summarized as mean, \pm standard deviation (SD) and median (minimum-maximum). Statistical analyses were performed using the Statistical Package for the Social Sciences (SPSS) for Windows package software version 13.0.

\section{RESULTS}

During the study period, of 1108 trauma patients admitted to our ED, 829 were male and 279 were female, with a mean age of 32 years and a male/female ratio of 2.9. Of those patients, 100 had multiple traumas. Of these, 78 patients were male and 22 were female, with a male to female ratio of 3.5. Patients' ages ranged between 15 and 70 years, with an average age of $33.2 \pm 15.4$ years.

Of all cases, 3 patients had previous trauma history while 4 suffered from cardiac failure. Additionally, the medical history of patients revealed that 2 had previous myocardial infarction, 1 had arrhythmia and another had both arrhythmia and cardiac failure. Examining these cases, abnormal electrocardiogram (ECG), CK-MB, CK, and CK-MB/CK were found in 4 patients, ECHO and TnT were abnormal in 3 patients and TNF-alpha was abnormal in 1 patient. The ECG and ECHO results are shown in Table 1.

ECG was abnormal in 63 patients and normal in the remaining 37 patients. The most common finding was sinus tachycardia, followed by right branch block. ST-T wave change, a finding that might indicate myocardial damage, was seen in 10 patients. Of these 10 cases revealing ST-T changes, ECHO revealed abnormal findings in 4 patients (functional defect of ventricles and pericardial effusion); CK-MB levels were abnormal in 7 patients, while TnT and TNF-alpha were abnormal in 4 patients. Furthermore, abnormal $\mathrm{CK}-\mathrm{MB} / \mathrm{CK}$ ratio was detected in all 10 patients.

Examining ECHO results, findings were normal 
Table 1. Distribution of abnormal ECG and ECHO findings of patients

\begin{tabular}{lc}
\hline Abnormal ECG findings & $\begin{array}{c}\text { Number of } \\
\text { Patients (n) }\end{array}$ \\
\hline Arrhythmia & 36 \\
$\quad$ Sinus tachycardia & 4 \\
Sinus bradycardia & \\
Damage of heart muscle & 10 \\
$\quad$ ST-T wave disorders & \\
Conduction system disorders & 13 \\
$\quad$ Right bundle block & 63 \\
Total & $\mathrm{n}$ \\
Abnormal ECHO findings & 2 \\
Pleural effusion & 1 \\
Pericardial effusion & 20 \\
Ventricular wall motion abnormality & 1 \\
Pericardial effusion + cardiac muscular laceration & 1 \\
Pericardial effusion + left ventricular wall motion abnormality & 3 \\
Cardiac valve disorders + left ventricular wall motion abnormality & 3 \\
Interventricular septum wall motion abnormality & 31 \\
Total & \\
\hline
\end{tabular}

Table 2. Accompanying injuries and abnormal findings

\begin{tabular}{lccccc}
\hline Diseases & $\begin{array}{c}\text { Number of } \\
\text { Patients }\end{array}$ & $\begin{array}{c}\text { Abnormal } \\
\text { ECG }\end{array}$ & $\begin{array}{c}\text { Abnormal } \\
\text { ECHO }\end{array}$ & $\begin{array}{c}\text { Abnormal } \\
\text { TnT }\end{array}$ & $\begin{array}{c}\text { Abnormal } \\
\text { CK-MB }\end{array}$ \\
\hline Pulmonary contusion & 13 & 12 & 3 & 1 & 5 \\
Hemothorax & 3 & 3 & 2 & 2 & - \\
Isolated pneumothorax & 1 & 1 & 1 & - & - \\
Hemopneumothorax & 3 & 3 & 1 & - & - \\
Sternum fracture & 3 & 1 & 3 & - & 3 \\
Scapula fracture & 4 & 1 & 1 & - & - \\
Clavicle fractures & 8 & 2 & - & - & 2 \\
Rib fractures & 21 & 12 & 13 & 4 & 8 \\
1st, 2nd and 3rd rib fractures & 9 & 4 & 2 & 1 & 8 \\
Flail chest & 10 & 4 & 6 & 1 & 5 \\
\hline
\end{tabular}

in 65 patients, and of the remaining, abnormal findings were detected in 31 patients. The most common abnormal finding on ECHO was ventricular function defect. ECG findings were also abnormal in 19 of those 31 cases with abnormal ECHO. Of these 31 cases, CK-MB/CK, CK-MB, TNF-alpha, and TnT were abnormal in $17,13,5$, and 4 cases, respectively. Furthermore, according to ISS, 16 patients with abnormal ECHO findings were in the severely damaged group.

Of 65 patients with normal ECHO, 37 showed abnormal ECG, 64 had abnormal CK levels, and 60 showed abnormal CK-MB/CK. Abnormal levels of CK-MB, TNF-alpha and TnT were detected in 45, 30 and 5 patients, respectively. The relationship of accompanying injuries and abnormal findings is shown in Table 2.

The relationship between trauma scales and cardiac markers, admission-hospitalization, and discharge periods is shown in Table 3. The hospitalization period was prolonged in parallel to an extended period before presentation to the hospital. A positive correlation was determined between the hospitalization period and ISS, GCS and RTS; with increasing trauma severity, the hospitalization period was also increased. Additionally, ISS increased in conjunction with extending duration before presentation. Evaluating the relationship of cardiac markers and trauma score, it was determined that TnT, CK-MB and CK showed a positive correlation with ISS, while a negative correlation was determined between TnT and RTS. Additionally, a negative correlation was determined between CK-MB and RTS and GCS. Similarly, there was a negative correlation between CK-MB/CK and GCS. However, there was no statistically significant relationship between levels of TNF-alpha and the trauma scales $(\mathrm{p}>0.05)$. 
Table 3. The correlation coefficient ( $\mathrm{r}$ ) between trauma scales and cardiac markers, admission-hospitalization and discharge period

\begin{tabular}{|c|c|c|c|c|c|c|c|c|c|c|}
\hline & & $\mathrm{CKMB} / \mathrm{CK}$ & CK-MB & TnT & TNF & GCS & ISS & RTS & $\begin{array}{l}\text { Admission } \\
\text { period }\end{array}$ & $\begin{array}{c}\text { Hopitalization } \\
\text { period }\end{array}$ \\
\hline \multirow[t]{2}{*}{$\mathrm{CK}$} & $\mathrm{r}$ & -0.262 & 0.609 & 0.186 & -0.011 & -0.127 & 0.373 & -0.177 & 0.300 & 0.379 \\
\hline & $\mathrm{p}$ & 0.008 & 0.000 & 0.064 & 0.915 & 0.209 & 0.000 & 0.078 & 0.002 & 0.000 \\
\hline \multirow[t]{2}{*}{$\mathrm{CKMB} / \mathrm{CK}$} & $\mathrm{r}$ & & 0.303 & 0.164 & -0.082 & -0.197 & 0.263 & -0.126 & -0.096 & -0.129 \\
\hline & $\mathrm{p}$ & & 0.002 & 0.103 & 0.415 & 0.049 & 0.008 & 0.212 & 0.340 & 0.200 \\
\hline \multirow[t]{2}{*}{ CKMB } & $\mathrm{r}$ & & & 0.402 & -0.153 & -0.249 & 0.460 & -0.205 & 0.189 & 0.247 \\
\hline & $\mathrm{p}$ & & & 0.000 & 0.127 & 0.013 & 0.000 & 0.041 & 0.060 & 0.013 \\
\hline \multirow[t]{2}{*}{ TnT } & $\mathrm{r}$ & & & & -0.121 & -0.189 & 0.405 & -0.171 & 0.209 & 0.099 \\
\hline & $\mathrm{p}$ & & & & 0.231 & 0.060 & 0.000 & 0.089 & 0.037 & 0.327 \\
\hline \multirow[t]{2}{*}{ TNF } & $\mathrm{r}$ & & & & & 0.130 & -0.206 & 0.131 & -0.036 & -0.133 \\
\hline & $\mathrm{p}$ & & & & & 0.196 & 0.039 & 0.194 & 0.724 & 0.187 \\
\hline \multirow[t]{2}{*}{ GCS } & $\mathrm{r}$ & & & & & & -0.607 & 0.924 & -0.053 & -0.279 \\
\hline & $\mathrm{p}$ & & & & & & 0.000 & 0.000 & 0.598 & 0.005 \\
\hline \multirow[t]{2}{*}{ ISS } & $\mathrm{r}$ & & & & & & & -0.548 & 0.387 & 0.339 \\
\hline & $\mathrm{p}$ & & & & & & & 0.000 & 0.000 & 0.001 \\
\hline \multirow[t]{2}{*}{ RTS } & $\mathrm{r}$ & & & & & & & & -0.078 & -0.291 \\
\hline & $\mathrm{p}$ & & & & & & & & 0.439 & 0.003 \\
\hline \multirow[t]{2}{*}{ Application } & $\mathrm{r}$ & & & & & & & & & 0.280 \\
\hline & $\mathrm{p}$ & & & & & & & & & 0.005 \\
\hline
\end{tabular}

CK: Creatine inase; CK-MB: Creatine kinase-MB fraction; RTS: Revised Trauma Score; ISS: Injury Severity Score; GCS: Glasgow Coma Scale; TnT: Troponin T.

Evaluating patients according to vital signs during presentation, high fever was present in 1 patient, tachycardia in 75 patients and shock in 10 patients, while 5 patients needed mechanical ventilation. Six of the 10 patients in shock and 4 of 5 mechanically ventilated patients died. It was determined that the CK-MB levels of patients in shock were as follows: Of these, TnT level was high in 1 and abnormal ECHO findings were determined in 2 patients, while other cardiac indicators were normal. CK, CK-MB/CK, CK-MB, TNF-alpha and TnT levels were outside normal range in 93, 90, 70, 40, and 11 cases, respectively (Table 3 ).

The relationship between vital signs, trauma scores and cardiac injury markers with respect to the prognosis is shown in Table 4 . Of 85 patients who underwent a medical intervention at another center, prior to admitting to our department, 19 (22.4\%) died; however, none of the patients who transferred directly to our department without any intervention died $(\mathrm{p}=0.04)$. Of 24 patients resuscitated at the trauma site, $9(37.5 \%)$ died, while only 10 of 76 patients $(13.2 \%)$ who had not been resuscitated at the trauma site died $(\mathrm{p}=0.008)$. Trauma scores (GCS, ISS, RTS) were found to be significantly different between these two groups. Five $(22.7 \%)$ of 22 female patients died, while $14(17.9 \%)$ of 78 male patients died $(p=0.614)$. The mean age of exitus cases was $35.9 \pm 18.1$ years, while the mean age of surviving patients was $32.6 \pm 14.8$ years $(p=0.411)$.

\section{DISCUSSION}

Trauma, one of the most important health problems for our country, commonly affects younger aged individuals and is responsible for considerable physical damage. Approximately $20 \%$ of the patients admitted to the ED included patients with chest trauma. ${ }^{[6,7]}$ Traffic collisions are the leading causes of morbidity and mortality worldwide, and a review of the literature revealed that $20 \%$ of deaths due to traffic collisions are sourced from trauma-related cardiac injuries. ${ }^{\left[{ }^{[, 9]}\right.}$ In this regard, determining cardiac involvement in traffic collision cases is of high importance to tackle multiple trauma cases and decrease the number of deaths.

Studies aiming to reveal cardiac involvement have been focused mostly on patients with an isolated chest trauma. On the other hand, it has been stated that determining cardiac injuries in multiple trauma cases is a very complex issue. ${ }^{[10]}$

According to Advanced Trauma Life Support (ATLS), a trauma program of the American College of Surgeons, an accurate diagnosis of cardiac contusions can be established by directly observing the myocardium. A previously conducted study revealed myocardial contusion during autopsy in $14 \%$ of deaths due to blunt trauma ${ }^{[11]}$ In order to diagnose cardiac contusion or other cardiac injuries, tests such as ECG, ECHO, blood levels of CK-MB and $\mathrm{CK}-\mathrm{MB} / \mathrm{CK}$ ratio were used in the present study.

Changes in ECG are non-specific and are not re- 
Table 4. The relationship of factors with prognosis*

\begin{tabular}{|c|c|c|c|c|}
\hline & Total & Discharge with healing & Death & $p$ \\
\hline \multicolumn{5}{|l|}{ Gender } \\
\hline Female/Male (n) & $22 / 78$ & $17 / 64$ & $5 / 14$ & 0.61 \\
\hline \multicolumn{5}{|l|}{ Interventions in other institutions } \\
\hline $\mathrm{No} /$ Yes $(\mathrm{n})$ & $15 / 85$ & $15 / 66$ & $0 / 19$ & 0.04 \\
\hline \multicolumn{5}{|l|}{ Trauma interventions at site } \\
\hline \multirow[t]{3}{*}{ No/Yes (n) } & $76 / 24$ & $66 / 15$ & $10 / 9$ & 0.008 \\
\hline & Mean \pm SD & Mean \pm SD & Mean \pm SD & \\
\hline & Med (min-max) & Med (min-max) & Med (min-max) & \\
\hline \multirow{2}{*}{ Temperature $\left(\mathrm{C}^{\circ}\right)$} & $36.6 \pm 0.6$ & $36.6 \pm 0.5$ & $36.6 \pm 0.7$ & 0.828 \\
\hline & $36.5(35-39.8)$ & $36.5(36-39.8)$ & $36.5(35-38)$ & \\
\hline \multirow[t]{2}{*}{ Pulse (minute) } & $95.1 \pm 19.8$ & $95.5 \pm 19.1$ & $93.8 \pm 23.4$ & 0.532 \\
\hline & $97.0(44-148)$ & $99(46-130)$ & $96(44-148)$ & \\
\hline \multirow[t]{2}{*}{ Systolic blood pressure (mmHg) } & $124.5 \pm 23.4$ & $125.5 \pm 18.4$ & $120.0 \pm 39.3$ & 0.209 \\
\hline & $120(60-190)$ & $120(75-180)$ & $110(60-90)$ & \\
\hline \multirow[t]{2}{*}{ Diastolic blood pressure $(\mathrm{mmHg})$} & $77.8 \pm 15.5$ & $79.4 \pm 13.7$ & $70.6 \pm 20.5$ & 0.092 \\
\hline & $80(30-120)$ & $80(55-120)$ & $70(30-110)$ & \\
\hline \multirow[t]{2}{*}{ Respiration (minute) } & $22.1 \pm 4.3$ & $21.8 \pm 4.4$ & $23.5 \pm 3.3$ & 0.079 \\
\hline & $20(5-36)$ & $20(5-36)$ & $24(18-28)$ & \\
\hline \multirow[t]{2}{*}{ Pulse oximeter } & $95.5 \pm 7.4$ & $96.5 \pm 6.6$ & $90.9 \pm 9.1$ & 0.003 \\
\hline & $100(65-100)$ & $100(65-100)$ & $92(70-100)$ & \\
\hline \multirow[t]{2}{*}{ CK-MB (ng/ml) } & $14.3 \pm 13.3$ & $13.0 \pm 12.8$ & $19.9 \pm 14.2$ & 0.030 \\
\hline & $9.3(1.1-56.7)$ & $8.1(1.15-56.7)$ & $17.9(2.5-54.3)$ & \\
\hline \multirow[t]{2}{*}{$\operatorname{TnT}(\mathrm{ng} / \mathrm{ml})$} & $0.053 \pm 0.125$ & $0.032 \pm 0.074$ & $0.143 \pm 0.226$ & 0.001 \\
\hline & $0.010(0.010-0.730)$ & $0.010(0.010-0.400)$ & $0.010(0.010-0.730)$ & \\
\hline \multirow[t]{2}{*}{ TNF-alpha (pg/ml) } & $4.2 \pm 10.3$ & $4.6 \pm 11.4$ & $2.8 \pm 1.1$ & 0.004 \\
\hline & $3(0.3-105)$ & $3(0.3-105)$ & $2.6(1.5-5.2)$ & \\
\hline \multirow[t]{2}{*}{ CK (U/L) } & $1908.7 \pm 4543.7$ & $2035.2 \pm 4983.1$ & $1369.1 \pm 1675.3$ & 0.785 \\
\hline & $778(66-39950)$ & $760(66-39950)$ & $836(79-7547)$ & \\
\hline \multirow[t]{2}{*}{ CK-MB/CK } & $0.013 \pm 0.010$ & $0.011 \pm 0.007$ & $0.021 \pm 0.014$ & 0.001 \\
\hline & $0.010(0.001-0.070)$ & $0.010(0.001-0.040)$ & $0.018(0.005-0.070)$ & \\
\hline \multirow[t]{2}{*}{ GCS } & $12.1 \pm 3.8$ & $12.9 \pm 3.1$ & $8.8 \pm 4.6$ & 0.0001 \\
\hline & $15(3-15)$ & $15(5-145)$ & $7(3-15)$ & \\
\hline \multirow[t]{2}{*}{ ISS } & $28.0 \pm 15.0$ & $24.9 \pm 13.5$ & $41.4 \pm 14.2$ & 0.0001 \\
\hline & $24(6-66)$ & $22(6-66)$ & $43(14-66)$ & \\
\hline \multirow[t]{2}{*}{ RTS } & $7.1 \pm 1.2$ & $7.3 \pm 0.8$ & $6.1 \pm 1.7$ & 0.002 \\
\hline & $7.84(1.46-7.93)$ & $7.84(4.15-7.84)$ & $5.96(1.46-7.93)$ & \\
\hline
\end{tabular}

*Intervention during another hospitalization-intervention at trauma site; CK: Creatine inase; CK-MB: Creatine kinase-MB fraction;

RTS: Revised Trauma Score; ISS: Injury Severity Score; GCS: Glasgow Coma Scale; TnT: Troponin T.

garded as a strong indicator for myocardial contusion in trauma cases; however, it might be indicative of cardiac involvement and of certain complications. ${ }^{[12,13]}$

A meta-analysis by Maenza et al. ${ }^{[14]}$ showed a concordance between important cardiac complications and abnormal ECG findings. It has been reported that every kind of arrhythmia can be diagnosed, while sinus tachycardia, ST-T wave change, ventricular fibrillation, premature atrial and ventricular discharges, atrial fibrillation, and AV blocks have a higher frequency of occurrence and of being diagnosed..$^{[12,14,15]}$

In our study, abnormal ECG finding was determined in 63 of 100 patients. Of these, sinus tachycardia was detected in $36 \%$, right branch block in $13 \%$, ST-T wave changes in $10 \%$, and sinus bradycardia in $4 \%$. Since ECG changes might be secondary to multiple traumas, the coherency of ECG findings and cardiac enzymes and ECHO was taken into account for the differential diagnosis of cardiac injuries. ST-T wave changes as an index of cardiac injury was determined in 10 patients. Of these, abnormal ECHO findings (ventricular function disorder and pericardial effusion) were detected in four patients, abnormal CK-MB levels in seven, and abnormal TnT and TNFalpha in four patients. Furthermore, CK-MB/CK was abnormal in all patients with abnormal ST-T changes. Abnormal ECHO was found in 12 of 36 patients with sinus tachycardia. It was noted that three patients with abnormal ECHO findings died following hospitalization.

A previously conducted study monitoring 68 patients by ECHO, ECG and CK-MB revealed that 49 patients had abnormal findings of any of ECHO, ECG or CK-MB tests. ${ }^{[15]}$ 
On the other hand, a statistically significant relationship between ECG changes and ECHO findings was reported in a study dealing with a series of 81 patients by Weiss et al. ${ }^{[16]}$ Abnormal ECHO findings (ventricular function disorders and pleural effusion) were detected in eight of 15 exitus cases.

In the literature, ECHO, ECG findings and cardiac enzymes have been stated to have a high possibility of being abnormal in patients with cardiac injuries secondary to chest trauma. ${ }^{[17,18]}$

ECHO findings were normal in $65 \%(n=65)$ of cases, while abnormal ECHO findings were revealed in $31 \%(n=31)$ in the present series. The most common finding was ventricular wall motion abnormality as detected in $20 \%$ of cases. In accordance with the literature, abnormal ECG findings were determined in 19 of 31 patients with abnormal ECHO findings. According to ISS, of 31 patients with abnormal ECHO findings, 16 were in the severely damaged group. Thus, ECHO evaluation in the ED of patients with high ISS is of high importance for early diagnosis and treatment.

Since skeletal muscle damage causes an increase in levels of CK-MB, such cases require a differential diagnosis from those cases involving myocardial damage. When evaluating trauma patients to determine the cardiac involvement, it has been stated that $\mathrm{CK}-\mathrm{MB}$ is increased, and $\mathrm{CK}-\mathrm{MB} / \mathrm{CK}$ rates lower than $2.2 \%$ were accepted as abnormal. Furthermore, a correlation between increased CK-MB levels and ECHO, ECG and other cardiac enzymes was reported. Therefore, increased CK-MB is accepted as indicative of cardiac injuries. ${ }^{[19,20]}$

In our series, CK-MB levels ranged between 1.15$289.0 \mathrm{ng} / \mathrm{ml}$, with an average level of $18.61 \mathrm{ng} / \mathrm{ml}$. $\mathrm{CK}-\mathrm{MB} / \mathrm{CK}$ ratio varied between 0 and 0.7 . The $\mathrm{CK}$, $\mathrm{CK}-\mathrm{MB} / \mathrm{CK}$ and $\mathrm{CK}-\mathrm{MB}$ values were found outside normal range in 93, 90 and 70 patients, respectively. A statistically significant relationship was determined between CK-MB and ISS, TnT, CK, and CK-MB/CK values $(p=0.00)$. A negative correlation was determined between CK-MB and RTS and GCS. In other words, high CK-MB levels were detected in patients with low RTS and GCS. There was no significant relationship between levels of CK-MB and TNF ( $p=0.18)$. Additionally, there was a statistically significant relationship between $\mathrm{CK}-\mathrm{MB} / \mathrm{CK}$ and $\mathrm{CK}-\mathrm{MB}$, and $\mathrm{CK}$ and $\mathrm{CK}-\mathrm{MB}$, and ISS as well $(\mathrm{p}=0.00)$. Furthermore, in parallel to the delay in presentation to the hospital, CK-MB and CK-MB/CK values were increased with increasing trauma severity and hospitalization duration.

In light of the above-mentioned data, it is important that patients with high severity points on trauma scales be conveyed to an appropriate health center with full facilities providing quick treatment, which might help to decrease the levels of cardiac injury markers.

TnT, a regulatory protein for myocardial contraction, which is released due to myocyte damage, is not released from skeletal muscle. In the literature, TnT is reported to have a higher sensitivity and specificity compared to other cardiac injury markers, and is stated to be more valuable than $\mathrm{CK}-\mathrm{MB}$ for the purpose of diagnosis. ${ }^{[20,21]}$

Abnormal TnT values (over $0.1 \mathrm{ng} / \mathrm{ml}$ ) were detected in 11 patients in our series. Of these, only three patients had a history of cardiac disease. Comparison of TnT with other diagnostic markers revealed that there was a statistically significant relation between CK-MB, ISS and TnT ( $\mathrm{p}=0.00)$. Furthermore, increase in TnT and CK-MB levels showed a concordance with increased trauma severity scale. Abnormal ECHO findings were determined in four and abnormal ECG was determined in nine of 11 patients with abnormal TnT levels. Use of TnT levels, in addition to the examination of CK-MB, ECHO, ECG, and ISS, was found to be highly valuable in the diagnosis of cardiac injury.

It has been stated that serum TNF levels are increased in circumstances such as blunt trauma, myocardial infarction, cardiopulmonary bypass surgery, congestive cardiac failure, and myocarditis. ${ }^{[22,23]}$ TNFalpha was used as a supportive diagnostic tool to determine cardiac involvement. It was determined that TNF-alpha levels ranged between 0.3-105 pg/ml, with an average level of $4.2 \mathrm{pg} / \mathrm{ml}$. However, it was not statistically significant $(p>0.05)$ when evaluating the coherence of cardiac injury indicators. Of 40 patients with high TNF-alpha levels, only one had a history of cardiac disease (TNF $5.1 \mathrm{pg} / \mathrm{ml}$ ). Of these, abnormal ECG was determined in 10 cases and abnormal ECHO in five cases. In the literature, it was stated that TNFalpha levels increase in the late period of cardiac injuries. Based on this statement, since our cases were evaluated in the acute period, no increase in TNFalpha levels was determined. Although the diagnostic value of TNF-alpha alone is low, it is valuable as a support for other tests.

Trauma-related researches generally focus on developing and implementing an efficient trauma scoring system through comparing the findings of patients with multiple traumas, which would be useful for patient care. A statistically significant relationship was reported between cardiac contusion and high ISS values $(\mathrm{p}<0.00)$.

There was a statistically significant difference in levels of CK-MB and CK between the slight and severe injury groups $(p=0.00)$; however, no significant difference was detected in our series regarding the remaining cardiac injury markers $(p>0.05)$. Abnormal 
ECHO was determined in 22 patients while ECG was abnormal in 26 patients in the severely damaged group according to ISS. Increase in the CK-MB level due to multiple traumas, which is specific for cardiac injury, shows the importance of ISS in cardiac injury secondary to multiple traumas. In this regard, the specificity of CK-MB and CK levels to determine cardiac injury severity is higher with ISS than with other trauma scales.

In conclusion, cardiac injury due to multiple trauma, those including chest trauma in particular, is responsible for high morbidity and mortality. ECG remains a sensitive test for diagnosis of blunt cardiac injuries. Especially in the cases with abnormal ECG, evaluating the troponin levels is of high importance for determining increased risk of death. Of cases with blunt chest trauma, those with cardiac disease history, hemodynamic instability, abnormal ECG, high troponin and CK-MB levels, and high trauma severity scores should be followed using intensive cardiac monitoring. Furthermore, those chest trauma patients admitted with chest pain, rib and sternum fractures, and lung damage should also be followed for at least the first 24 hours for blunt cardiac injury. Those patients should additionally be evaluated by ECHO to diagnose and treat possible pericardial tamponade in the early period.

\section{REFERENCES}

1. Battistella FD, Benfield JR. Blunt and penetrating injuries of the chest wall, pleura and lungs. In: Shield TW, editor. General thoracic surgery. 5th ed. Philadelphia: Williams and Wilkins; 2000. p. 815-63.

2. Şentürk E, Doğan Y, Yoldaş E. Thoracic trauma: analysis of 1142 cases. Turkish Thoracic Journal 2010;11:47-54.

3. Saadeddin SM, Habbab MA, Sobki SH, Ferns GA. Minor myocardial injury after elective uncomplicated successful PTCA with or without stenting: detection by cardiac troponins. Catheter Cardiovasc Interv 2001;53:188-92.

4. Bertinchant JP, Polge A, Mohty D, Nguyen-Ngoc-Lam R, Estorc J, Cohendy R, et al. Evaluation of incidence, clinical significance, and prognostic value of circulating cardiac troponin I and T elevation in hemodynamically stable patients with suspected myocardial contusion after blunt chest trauma. J Trauma 2000;48:924-31.

5. Maass DL, Hybki DP, White J, Horton JW. The time course of cardiac NF-kappaB activation and TNF-alpha secretion by cardiac myocytes after burn injury: contribution to burnrelated cardiac contractile dysfunction. Shock 2002;17:2939.

6. Buchman TG, Hall BL, Bowling WM, Kelen GD. Thoracic trauma. In: Tintinalli JE, Kelen GD, Stapczynski JS, editors. Emergency medicine: a comprehensive study guide. New York: McGraw-Hill; 2004. p. 1595-613.

7. Balcı AE, Eren N, Eren Ş, Ülkü R, Onat S, Cebeci E. Fac- tors influencing mortality in trauma thoracotomy. Journal of Turkish Chest Cardiac Vein Surgery 2001;9:215-20.

8. Burgut HR, Bener A, Sidahmed H, Albuz R, Sanya R, Khan WA. Risk factors contributing to road traffic crashes in a fast-developing country: the neglected health problem. Ulus Travma Acil Cerrahi Derg 2010;16:497-502.

9. Kapadıa SR, Topol EJ. Cardiac trauma. In: Topol EJ, editor. Textbook of cardiovascular medicine. Ohio: Cordisgroup; 2005. p. 901-15.

10. Gumanenko EK, Kochergaev OV, Gavrilin SV, Nemchenko NS, Boiarintsev VV. Diagnosis of heart contusions in patients with multiple trauma of the chest. [Article in Russian] Vestn Khir Im I I Grek 2000;159:36-40.

11. Bansal MK, Maraj S, Chewaproug D, Amanullah A. Myocardial contusion injury: redefining the diagnostic algorithm. Emerg Med J 2005;22:465-9.

12. Potkin RT, Werner JA, Trobaugh GB, Chestnut CH 3rd, Carrico CJ, Hallstrom A, et al. Evaluation of noninvasive tests of cardiac damage in suspected cardiac contusion. Circulation 1982;66:627-31.

13. Fang BR, Li CT. Acute myocardial infarction following blunt chest trauma. Eur Heart J 1994;15:705-7.

14. Maenza RL, Seaberg D, D’Amico F. A meta-analysis of blunt cardiac trauma: ending myocardial confusion. Am J Emerg Med 1996;14:237-41.

15. Yuan Y, Ren J, Zhang W, Chen J, Li J. The effect of different temporary abdominal closure materials on the growth of granulation tissue after the open abdomen. J Trauma 2011;71:961-5.

16. Weiss RL, Brier JA, O’Connor W, Ross S, Brathwaite CM. The usefulness of transesophageal echocardiography in diagnosing cardiac contusions. Chest 1996;109:73-7.

17. Wiener Y, Achildiev B, Karni T, Halevi A. Echocardiogram in sternal fracture. Am J Emerg Med 2001;19:403-5.

18. Markiewicz W, Best LA, Burstein S, Peleg H. Echocardiographic evaluation after blunt trauma of the chest. Int J Cardiol 1985;8:269-74.

19. Pasquale MD, Nagy K, Clarke J. Practice management guidelines for screening of blunt cardiac injury. In: Practice management guidelines for trauma. The EAST Practice Management Guidelines Work Group: Eastern Association For The Surgery of Trauma, 1998. Available from URL: http://www. east.org/tpg/chap2.pdf [Accessed July, 2012].

20. Fulda GJ, Giberson F, Hailstone D, Law A, Stillabower M. An evaluation of serum troponin $\mathrm{T}$ and signal-averaged electrocardiography in predicting electrocardiographic abnormalities after blunt chest trauma. J Trauma 1997;43:304-12.

21. Riou B. Troponin: important in severe trauma and a first step in the biological marker revolution. Anesthesiology 2004;101:1259-60.

22. Latini R, Bianchi M, Correale E, Dinarello CA, Fantuzzi $\mathrm{G}$, Fresco C, et al. Cytokines in acute myocardial infarction: selective increase in circulating tumor necrosis factor, its soluble receptor, and interleukin-1 receptor antagonist. J Cardiovasc Pharmacol 1994;23:1-6.

23. Pomerantz BJ, Reznikov LL, Harken AH, Dinarello CA. Inhibition of caspase 1 reduces human myocardial ischemic dysfunction via inhibition of IL-18 and IL-1beta. Proc Natl Acad Sci U S A 2001;98:2871-6. 